\title{
HUBUNGAN PENGETAHUAN TERAPI DIET DENGAN INDEKS GLIKEMIK BAHAN MAKANAN YANG DIKONSUMSI PASIEN DIABETES MELLITUS
}

\author{
Bertalina $^{1}$, Anindyati ${ }^{2}$ \\ 1,2 Jurusan Gizi, Politeknik Kesehatan Tanjungkarang \\ Email: ubertalina@yahoo.com
}

\begin{abstract}
Relationship between Knowledge of Diet Therapy on Glycemic Index Foods that were Eaten by Patients with Diabetes Mellitus. National prevalence of Diabetes mellitus at age $\geq 15$ years was $2.1 \%$ and $0.8 \%$ in Lampung (Riskesdas, 2013). In the Bandar Lampung city, the prevalence of Diabetes mellitus was equal to 0.9\% (Riskesdas, 2007 and 2013). Number of patients with Diabetes mellitus in 2015, as many as, 524 patients and ranks second out of 10 diseases in Poli Disease Hospital Dr. H. Abdul Moeloek Lampung Province in 2015. This research was to determine the relationship of knowledge about dietary therapy with glycemic index foods that were consumed by patients with Diabetes mellitus type II, in Poli Disease Hospital Dr. H. Abdul Moeloek, Lampung Province. Cross sectional approach were used. The univariate analysis showed that majority distribution of the characteristics of the respondent were female $(56.7 \%)$, most respondents aged were 51-60 years (43.3\%) and the age of initial respondents most affected by type 2 diabetes mellitus were $41-50$ years $(40 \%)$, most respondents last education were high school $(36.7 \%)$, most jobs were housewives $(46.7 \%)$, and the majority of respondents had nutritional counseling by a nutritionist $(63.3 \%)$. Distribution of knowledge about diet therapy mostly good $(70 \%)$. Majority the glycemic index of foods that had consumed by respondents were high $(53.3 \%)$. There was a significant association between knowledge of diet therapy with glycemic index foods that were consumed by patients with Diabetes mellitus type II in Poli Disease Hospital Dr. H. Abdul Moeloek Lampung (p-value=0.001).
\end{abstract}

Keywords: Diabetes Mellitus Type II, Knowledge of diet therapy, Glycemic index

\begin{abstract}
Abstrak: Hubungan Pengetahuan Tentang Terapi Diet dengan Indeks Glikemik Bahan Makanan yang Dikonsumsi Pasien Diabetes mellitus. Prevalensi nasional Diabetes mellitus pada umur $\geq 15$ tahun adalah 2,1\% dan pravalensi Diabetes mellitus pada Provinsi Lampung 0,8\% (Riskesdas 2013). Di kota Bandar Lampung, prevalensi penyakit Diabetes mellitus yaitu sebesar 0,9\% (Riskesdas 2007 dan Riskesdas 2013). Jumlah pasien Diabetes mellitus Tahun 2015 sebanyak 524 pasien dan menempati urutan ke-2 dari 10 penyakit terbanyak di Poli Penyakit Dalam RSUD Dr. H. Abdul Moeloek Provinsi Lampung pada tahun 2015. Tujuan dari penelitian ini adalah diketahuinya hubungan pengetahuan tentang terapi diet dengan indeks glikemik bahan makanan yang dikonsumsi pasien Diabetes mellitus tipe II di Poli Penyakit Dalam RSUD Dr. H. Abdul Moeloek Provinsi Lampung. Penelitian menggunakan pendekatan Cross Sectional. Berdasarkan hasil penelitian, diperoleh hasil analisis univariat distribusi karakteristik responden, diketahui bahwa jenis kelamin terbanyak adalah perempuan $(56,7 \%)$, umur responden terbanyak 51-60 tahun (43,3\%) dan umur awal responden terkena DM tipe 2 terbanyak 41-50 tahun (40\%).Pendidikan terakhir responden terbanyak adalah SMA (36,7\%), pekerjaan terbanyak adalah ibu rumah tangga $(46,7 \%)$ dansebagian besar responden pernah melakukan konsultasi gizi oleh ahli gizi $(63,3 \%)$. Distribusi pengetahuan tentang terapi diet sebagian besar baik (70\%). Distribusi indeks glikemik bahan makanan yang dikonsumsi responden sebagian besar tinggi (53,3\%). Ada hubungan yang bermakna antara pengetahuan tentang terapi diet dengan indeks glikemik bahan makanan yang dikonsumsi pasien Diabetes mellitus tipe II di Poli Penyakit Dalam RSUD Dr. H. Abdul Moeloek Provinsi Lampung (p-value 0,001).
\end{abstract}

Kata kunci: DM Tipe II, Pengetahuan tentang terapi diet, Indeks glikemik

Diabetes mellitus merupakan penyakit gangguan metabolisme glukosa di mana tubuh gagal atau kurang baik dalam mengontrol glukosa yang masuk dari makanan sehingga kadar gula darah tinggi. Diabetes dapat terjadi karena gangguan produksi insulin, resisten insulin (gkukosa tidak bisa masuk ke dalam sel), atau kombinasi dari keduanya (Prihaningtyas, 2013). 
Diabetes mellitus menjadi masalah kesehatan masyarakat utama di masyarakat karena komplikasinya bersifat jangka pendek dan jangka panjang. Hiperglikemia jangka panjang memengaruhi sistem pembuluh darah kecil pada mata, ginjal dan saraf serta arteri yang lebih mengarah pada percepatan terjadinya arteriosklerosis. Angka kematian akibat penyakit jantung iskemik dan stroke dua sampai empat kali lebih tinggi dibandingkan populasi yang tidak mengalami diabetes berdasarkan usia dan jenis kelamin (Bilous dan Donelly, 2014).

Jumlah penderita diabetes di Amerika Serikat mencapai 23,6 juta jiwa $(7,8 \%$ dari seluruh populasi). Jumlah penderita diabetes di seluruh dunia diproyeksikan akan meningkat lagi dari 171 juta jiwa pada tahun 2000 menjadi 366 juta jiwa pada tahun 2030 dan 90\%-nya dapat menderita diabetes tipe 2. Perubahan demografik penting terkait peningkatan pravalensi kasus Diabetes mellitus di seluruh dunia adalah pravalensi lansia (>65 tahun) (Bilous dan Donelly, 2014).

Pravalensi nasional Diabetes mellitus pada umur $\geq 15$ tahun berdasarkan diagnosis dokter dan gejala adalah $2,1 \%$ dan pravalensi Diabetes mellitus pada provinsi Lampung mengalami peningkatan dari $0,4 \%$ (Riskesdas 2007) menjadi 0,8\% (Riskesdas 2013). Di kota Bandar Lampung, prevalensi penyakit Diabetes mellitus yaitu sebesar 0,9\% (Riskesdas 2007 dan Riskesdas 2013). Prevalensi Diabetes mellitus tersebut berdasarkan diagnosis dokter dan gejala meningkat sesuai dengan bertambahnya umur, namun mulai umur $\searrow 65$ tahun cenderung menurun. Proporsi DM pada perempuan cenderung lebih tinggi, tetapi hampir sama antara proporsi di perkotaan $(6,8 \%)$ dan perdesaan $(7,0 \%)$.

Diabetes mellitus merupakan penyakit nomor lima terbanyak $(4,9 \%)$ pada pasien rawat jalan di setiap rumah sakit di Indonesia tahun 2010 dan peringkat ke empat penyakit tidak menular penyebab kematian yang mengalami peningkatan dari tahun 2009 yaitu 3,12\% menjadi 3,66\% di tahun 2010 (Kemenkes RI, 2012). Berdasarkan data rekam medik RSUD Dr. H. Abdul Moeloek Provinsi Lampung, jumlah pasien Diabetes mellitus di Poli Penyakit Dalam RSUD Dr. H. Abdul Moeloek Provinsi Lampung pada tahun 2015 menempati urutan ke-2 dari 10 penyakit terbanyak. Jumlah pasien Diabetes mellitus rawat jalan pada tahun 2010 terdapat 5744 pasien, pada tahun 2011 terdapat 4248 pasien, tahun 2013 sebanyak 6972 pasien, tahun 2014 sebanyak 896 pasien. Pada tahun 2015, jumlah pasien rawat jalan Diabetes mellitus terdapat 524 pasien. Sedangkan pada tahun 2016, hingga bulan April mencapai 144 pasien.

Penyakit diabetes melitus apabila dibiarkan tak terkendali akan dapat menimbulkan berbagai kerusakan atau komplikasi seperti kerusakan saraf, mata, ginjal, jantung, dan pembuluh darah. Diabetes dapat dikontrol dalam waktu yang lebih lama. Salah satu cara untuk mengendalikan Diabetes mellitus adalah dengan diet atau asupan makannya yang berhubungan dengan salah satu gejala Diabetes mellitus yaitu banyak makan. Keberhasilan dalam mematuhi anjuran diet tergantung dari kedisiplinan Penderita (Perkeni, 2011).

Diet merupakan bagian yang dianggap penting dalam penatalaksanaan DM tipe 2, selain olahraga, obat-obatan anti diabetik serta pendidikan. Memilih pangan (karbohidrat) yang tidak menaikkan kadar gula darah secara drastis merupakan salah satu upaya untuk menjaga kadar gula darah pada taraf normal (Maulana, 2008). Pengenalan karbohidrat berdasarkan efeknya terhadap kadar gula darah dan respons insulin dapat digunakan sebagai acuan dalam menentukan jumlah dan jenis pangan sumber karbohidrat yang tepat untuk meningkatkan dan menjaga kesehatan (Prihaningtyas, 2013). Konsumsi karbohidrat mempengaruhi secara langsung beban glikemik, dimana beban glikemik dapat mencerminkan respon insulin terhadap makanan. Indeks glikemik membantu penderita diabetes dalam menentukan jenis pangan karbohidrat yang dapat mengendalikan kadar glukosa darah. Dengan mengetahui indeks glikemik pangan, penderita diabetes dapat memilih makanan yang tidak menaikkan kadar glukosa darah secara drastis sehingga kadar glukosa darah dapat dikontrol pada tingkat yang aman (Rimbawan, 2004 dalam Ernawati 2013).

Berdasarkan penelitian yang dilakukan oleh Annisa (2015) mengenai hubungan konsumsi bahan makanan yang mengandung indeks glikemik dengan kadar gula darah pada pasien DM-tipe 2 di RSUD Abdul Moeloek, menunjukkan bahwa adanya hubungan yang bermakna antara indeks glikemik bahan makanan yang dikonsumsi dengan kadar gula darah pasien Diabetes mellitus tipe 2. Pangan yang mempunyai indeks glikemik tinggi bila dikonsumsi akan meningkatkan kadar gula dalam darah dengan cepat dan tinggi. Sebaliknya, seseorang yang mengonsumsi pangan berindeks glikemik rendah maka peningkatan kadar gula dalam darah berlangsung lambat dan puncak kadar gula darahnya rendah.

Kontrol glikemik pasien sangat dipengaruhi oleh kepatuhan pasien terhadap 
anjuran diet meliputi, jenis dan jumlah makanan yang dikonsumsi dan ketidakpatuhan merupakan salah satu hambatan untuk tercapainya tujuan pengobatan dan juga akan mengakibatkan pasien melakukan pemeriksaan atau pengobatan yang sebenarnya tidak diperlukan (Arsana, 2011 dalam Laili, dkk. 2012). Hasil penelitian yang dilakukan oleh Rusimah (2010) di ruang rawat inap RSUD Dr. H. Moch. Ansari Saleh Banjarmasin, menunjukkan bahwa terdapat hubungan yang bermakna antara kepatuhan diet pada diabetisi dengan pengetahuan gizi. Semakin tinggi tingkat pengetahuan gizi responden maka semakin besar pula persentase responden patuh terhadap dietnya.

Dalam penelitian Tandayu (2014) mengenai pengaruh motivasi, pengetahuan serta tindakan olahraga terhadap tindakan konsumsi pangan pelaku fitness usia dewasa tahun 2014, dijelaskan bahwa adanya hubungan nyata antara pengetahuan (baik pengetahuan kesehatan maupun gizi) dengan konsumsi karbohidrat berindeks glikemik rendah seperti nasi merah atau ubi. Serta terdapat hubungan yang bermakna antara pengetahuan gizi dengan konsumsi bahan makanan yang berindeks glikemik sedang seperti bihun $(p=0,041)$.

\section{METODE PENELITIAN}

Rancangan penelitian ini menggunakan penelitian secara analitik dengan pendekatan cross sectional. Karena penelitian ini dilakukan hanya satu kali pada saat yang bersamaan.
Dalam penggunaan studi cross sectional pengukuran variabel dependen (pengetahuan terapi diet) dan variabel independen (Indeks glikemik BM) dilakukan pada waktu yang bersamaan dan secara langsung.

Populasi pada penelitian ini adalah pasien Diabetes mellitus tipe 2 di Poli Penyakit Dalam RSUD Abdul Moeloek. Sampel penelitian ini adalah adalah pasien Diabetes mellitus tipe 2 di Poli Penyakit Dalam RSUD Abdul Moeloek. Sampel pada penelitian ini ditentukan berdasarkan pertimbangan peneliti dengan menggunakan kriteria inklusi.

\section{HASIL}

\section{A. ANALISIS UNIVARIAT}

\section{Jenis Kelamin}

Tabel 1. Distribusi Jenis Kelamin Responden Diabetes mellitus Tipe 2

\begin{tabular}{ccc}
\hline Jenis & \multicolumn{2}{c}{ Jumlah } \\
\cline { 2 - 3 } Kelamin & n & \% \\
\hline Laki-laki & 12 & 40 \\
Perempuan & 18 & 60 \\
\hline \multicolumn{1}{c}{ Jumlah } & 30 & 100 \\
\hline
\end{tabular}

Berdasarkan tabel di atas dapat diketahui jenis kelamin responden Diabetes mellitus tipe 2 di Poli Penyakit Dalam yaitu laki-laki berjumlah 12 orang dengan persentase $40 \%$ dan perempuan berjumlah 18 orang dengan persentase $60 \%$.

\section{Umur}

Tabel 2. Distribusi Umur Responden Diabetes mellitus Tipe 2

\begin{tabular}{|c|c|c|c|c|c|c|c|}
\hline \multirow[t]{2}{*}{ Umur Responden } & \multicolumn{2}{|c|}{ Jumlah } & \multirow[t]{2}{*}{ Umur Awal Menderita DM } & \multicolumn{2}{|c|}{ Jumlah } & \multicolumn{2}{|c|}{ Lama sakit (tahun) } \\
\hline & $\mathbf{n}$ & $\%$ & & $\mathbf{n}$ & $\%$ & Min. & Max. \\
\hline 27- 40 tahun & 2 & 6,7 & 27- 40 tahun & 7 & 23,3 & 0 & 18 \\
\hline $41-50$ tahun & 6 & 20 & $41-50$ tahun & 12 & 40 & & \\
\hline $51-60$ tahun & 13 & 43,3 & $51-60$ tahun & 9 & 30 & & \\
\hline$>60$ tahun & 9 & 30 & $>60$ tahun & 2 & 6,7 & & \\
\hline Jumlah & 30 & 100 & Jumlah & 30 & 100 & & \\
\hline
\end{tabular}

Dari tabel di atas dapat diketahui umur responden Diabetes mellitus tipe 2 paling banyak berada pada rentang umur 51-60 tahun yaitu 13 orang dengan persentase $43,3 \%$ dan paling sedikit berumur 27-40 tahun yaitu 2 orang dengan persentase $6,7 \%$. Namun umur awal responden menderita Diabetes mellitus tipe 2 paling banyak berumur 41-50 tahun yaitu 12 orang dengan persentase $40 \%$ dan paling sedikit berumur $>60$ tahun yaitu 2 orang dengan persentase $6,7 \%$. Selain itu, dari tabel diatas diketahui bahwa paling lama responden menderita sakit DM yaitu 18 tahun dan paling rendah $<1$ tahun.

\section{Pendidikan}

Tabel 3 menunjukkan bahwa pendidikan terakhir responden Diabetes mellitus tipe 2 yang paling banyak adalah SMA yaitu 11 orang 
dengan persentase sebesar $36,7 \%$ sedangkan pendidikan terakhir yang paling sedikit adalah tamatan SD dengan persentase $16,7 \%$ (5 orang).

Tabel 3. Distribusi Pendidikan Terakhir Responden Diabetes mellitus Tipe 2

\begin{tabular}{|c|c|c|}
\hline \multirow[t]{2}{*}{ Pendidikan } & \multicolumn{2}{|c|}{ Jumlah } \\
\hline & $\mathbf{n}$ & $\%$ \\
\hline SD & 5 & 16,7 \\
\hline SMP & 6 & 20 \\
\hline SMA & 11 & 36,7 \\
\hline Perguruan Tinggi & 8 & 26,7 \\
\hline Jumlah & 30 & 100 \\
\hline
\end{tabular}

\section{Pekerjaan}

Tabel 4. Distribusi Pekerjaan Responden Diabetes mellitus Tipe 2

\begin{tabular}{lrr}
\hline \multirow{2}{*}{\multicolumn{1}{c}{ Pekerjaan }} & \multicolumn{2}{c}{ Jumlah } \\
\cline { 2 - 3 } & \multicolumn{1}{c}{ n } & \multicolumn{1}{c}{$\%$} \\
\hline Ibu Rumah Tangga & 14 & 46,7 \\
PNS & 5 & 16,7 \\
Wiraswasta & 5 & 16,7 \\
Pegawai Swasta & 1 & 3,3 \\
Buruh & 2 & 6,7 \\
Pensiunan & 3 & 10 \\
\hline \multicolumn{1}{c}{ Jumlah } & 30 & 100 \\
\hline
\end{tabular}

Berdasarkan tabel 4 di atas dapat diketahui bahwa pekerjaan responden yang paling banyak adalah ibu rumah tangga yaitu 14 orang dengan persentase $46,7 \%$. Sedangkan pekerjaan responden yang paling sedikit adalah pegawai swasta yaitu 1 orang dengan persentase 3,3\%.

\section{Konsultasi Gizi}

Tabel 5. Distribusi Responden Diabetes mellitus Tipe 2 Mendapat Konsultasi Gizi

\begin{tabular}{lcc}
\hline Konsultasi Gizi & \multicolumn{2}{c}{ Jumlah } \\
\cline { 2 - 3 } & n & \% \\
\hline Pernah & 19 & 63,3 \\
Tidak pernah & 11 & 36,7 \\
\hline \multicolumn{1}{c}{ Jumlah } & 30 & 100 \\
\hline
\end{tabular}

Dari tabel 5 di atas dapat diliat bahwa responden Diabetes mellitus paling banyak pernah melakukan konsultasi gizi oleh petugas gizi yaitu 19 orang dengan persentase $63,3 \%$, sedangkan responden Diabetes mellitus yang tidak pernah melakukan konsultasi gizi oleh petugas gizi sebanyak 11 orang dengan persentase $36,7 \%$.

\section{Gambaran Pengetahuan Pasien tentang Terapi Diet}

Tabel 6. Distribusi Tingkat Pengetahuan Responden Diabetes mellitus Tipe 2

\begin{tabular}{lrr}
\hline \multirow{2}{*}{ Tingkat Pengetahuan } & \multicolumn{2}{c}{ Jumlah } \\
\cline { 2 - 3 } & \multicolumn{1}{c}{ n } & \% \\
\hline Baik & 21 & 70 \\
Kurang baik & 9 & 30 \\
\hline \multicolumn{1}{c}{ Jumlah } & 30 & 100 \\
\hline
\end{tabular}

Berdasarkan tabel 6 di atas dapat diketahui bahwa rata-rata responden memiliki tingkat pengetahuan yang baik yaitu sebanyak 21 orang atau $70 \%$. Sedangkan responden yang memiliki tingkat pengetahuan kurang baik hanya 9 orang atau sebesar $30 \%$.

\section{Gambaran Indeks Glikemik BM yang Dikonsumsi}

Berdasarkan tabel 7, dapat diketahui bahwa responden Diabetes mellitus tipe 2 yang mengonsumsi bahan makanan yang mengandung indeks glikemik rendah yaitu 14 orang dengan persentase sebesar $46,7 \%$, sedangkan sisanya responden mengonsumsi bahan makanan dengan indeks glikemik tinggi yaitu 16 orang dengan persentase $53,3 \%$.

Tabel 7. Distribusi Indeks Glikemik yang Dikonsumsi Responden Diabetes mellitus Tipe 2

\begin{tabular}{lcc}
\hline \multicolumn{1}{c}{ Jenis Indeks } & \multicolumn{2}{c}{ Jumlah } \\
\cline { 2 - 3 } Glikemik & n & \% \\
\hline IG rendah & 14 & 46,7 \\
IG tinggi & 16 & 53,3 \\
\hline \multicolumn{1}{c}{ Jumlah } & 30 & 100 \\
\hline
\end{tabular}

\section{B. ANALISIS BIVARIAT}

Hasil analisis hubungan pengetahuan tentang terapi diet dengan indeks glikemik bahan makanan yang dikonsumsi pasien Diabetes mellitus tipe 2 dapat dilihat pada tabel 8 di bawah ini.

Tabel 8. Distribusi Pengetahuan dengan BM Indeks Glikemik yang Dikonsumsi Pasien Diabetes mellitus Tipe 2

\begin{tabular}{|c|c|c|c|c|c|c|c|}
\hline \multirow{3}{*}{ Pengetahuan } & \multicolumn{4}{|c|}{$\begin{array}{l}\text { Jenis IG yang } \\
\text { dikonsumsi }\end{array}$} & \multirow{2}{*}{\multicolumn{2}{|c|}{ Jumlah }} & \multirow[t]{3}{*}{$\begin{array}{l}p \text { - } \\
\text { value }\end{array}$} \\
\hline & \multicolumn{2}{|c|}{ Rendah } & \multicolumn{2}{|c|}{ Tinggi } & & & \\
\hline & $\mathrm{n}$ & $\%$ & $\mathrm{n}$ & $\%$ & $\mathbf{n}$ & $\%$ & \\
\hline Baik & 14 & 66,7 & 7 & 33,3 & 21 & 100 & 0,001 \\
\hline Kurang baik & 0 & 0 & 9 & 100 & 9 & 100 & \\
\hline Jumlah & 14 & 46,7 & 16 & 53,3 & 30 & 100 & \\
\hline
\end{tabular}


Berdasarkan tabel di atas menunjukkan bahwa responden yang mengonsumsi bahan makanan dengan indeks glikemik rendah sebanyak 14 responden, terdapat 14 responden $(66,7 \%)$ memiliki pengetahuan yang baik dan sebanyak 0 responden $(0 \%)$ memiliki pengetahuan yang tidak baik tentang terapi diet. Sedangkan responden yang mengonsumsi bahan makanan dengan indeks glikemik tinggi sebanyak 16 responden, terdapat 7 responden $(33,3 \%)$ memiliki pengetahuan yang baik dan sebanyak 9 responden (100\%) memiliki pengetahuan yang tidak baik tentang terapi diet. Hasil uji statistik didapatkan $p$-value $0,001 \quad(p<0,05)$. Hal ini menunjukkan bahwa terdapat hubungan yang bermakna antara pengetahuan tentang terapi diet dengan indeks glikemik yang dikonsumsi.

\section{PEMBAHASAN}

\section{A. Gambaran Umum Responden}

\section{Jenis Kelamin}

Jenis kelamin merupakan jenis gender responden yang dibedakan menjadi dua, yaitu laki-laki dan perempuan. Berdasarkan dari hasil penelitian terhadap pasien Diabetes mellitus tipe 2, didapatkan bahwa kejadian Diabetes mellitus tipe 2 paling banyak pada perempuan dengan persentase sebesar $60 \%$ dibandingkan dengan jenis kelamin laki-laki yaitu sebesar $40 \%$.

Prihaningtyas (2013) menyebutkan bahwa faktor-faktor risiko yang dapat menyebabkan terjadinya Diabetes mellitus yaitu faktor yang dapat dimodifikasi dan tidak dapat dimodifikasi. Faktor yang tidak dapat dimodifikasi tersebut salah satunya adalah jenis kelamin.

Hasil penelitian ini sejalan dengan Trisnawati (2013) dan Haryati (2014) dimana dijelaskan kejadian DM Tipe 2 pada wanita lebih tinggi daripada laki-laki. Menurut Trisnawati (2013), wanita lebih berisiko mengidap diabetes karena secara fisik wanita memiliki peluang peningkatan indeks masa tubuh yang lebih besar. Sindroma siklus bulanan (premenstrual syndrome), pasca-menopause yang membuat distribusi lemak tubuh menjadi mudah terakumulasi akibat proses hormonal tersebut sehingga wanita berisiko menderita Diabetes mellitus tipe2. Sedangkan menurut Haryati (2014), hal tersebut karena pada perempuan memiliki LDL atau kolesterol jahat tingkat trigliserida yang lebih tinggi dibandingkan dengan laki-laki, dan juga terdapat perbedaan dalam melakukan semua aktivitas dan gaya hidup sehari-hari yang sangat mempengaruhi kejadian terjadinya penyakit Diabetes mellitus . Jumlah lemak pada laki-laki dewasa rata-rata berkisar antara 15-20\% dari berat badan total, dan pada perempuan sekitar 20-25\%. Jadi peningkatan kadar lipid (lemak darah) pada perempuan lebih tinggi dibandingkan pada lakilaki, sehingga faktor risiko terjadinya Diabetes mellitus pada perempuan 3-7 kali lebih tinggi dibandingkan pada laki-laki yaitu 2-3 kali.

Berbeda dengan Pramudiarja (2011), yang menyebutkan bahwa jenis kelamin laki-laki memiliki risiko diabetes meningkat lebih cepat. Dari hasil penelitiannya, laki-laki terkena diabetes pada IMT rata-rata $31,83 \mathrm{~kg} / \mathrm{m} 2$ sedangkan perempuan baru mengalaminya pada IMT 33,69 $\mathrm{kg} / \mathrm{m} 2$. Perbedaan risiko ini dipengaruhi oleh distribusi lemak tubuh. Pada laki-laki, penumpukan lemak terkonsentrasi di sekitar perut sehingga memicu obesitas sentral yang lebih berisiko memicu gangguan metabolisme.

\section{Umur}

Umur adalah masa hidup responden yang dinyatakan dalam suatu tahun dan sesuai tanggal lahir responden. Berdasarkan dari hasil penelitian diperoleh data bahwa sebagian besar pasien Diabetes mellitus yang menjadi sampel dalam penelitian berumur antara 51-60 tahun dengan persentase $43,3 \%$ dan paling sedikit berumur 27 40 tahun dengan persentase $6,7 \%$. Namun umur awal responden menderita Diabetes mellitus tipe 2 paling banyak berumur 41-50 tahun dengan persentase $40 \%$ dan paling sedikit berumur $>60$ tahun dengan persentase 6,7\%.

Menurut PERKENI (2011), umur merupakan salah satu faktor risiko Diabetes mellitus yang tidak dapat dimodifikasi. Risiko untuk menderita intoleransi glukosa meningkat seiring dengan meningkatnya usia. Hal ini dikarenakan pada usia tersebut akan berkurangnya gerak badan dan massa otot namun berat badan semakin bertambah. Hasil penelitian ini sesuai dengan teori Smeltzer and Bare (2001), usia tua berisiko mengalami diabetes karena kemampuan tubuh pada usia tua terjadi penurunan fungsi pankreas akibatnya fungsi pankreas untuk bereaksi terhadap insulin menurun. Glukosa dalam darah secara normal bersirkulasi dalam jumlah tertentu di dalam darah. Oleh karena ketidakmampuan pankreas untuk bekerja maka dapat mengakibatkan kadar glukosa glukosa dalam darah meningkat.

Menurut Helmawati (2014), orang dengan usia 40 tahun mulai memiliki risiko terkena diabetes. Selanjutnya dengan semakin bertambahnya usia maka semakin besar pula 
risiko seorang mengalami Diabetes mellitus tipe 2. Hal ini disebabkan karena usia yang bertambah membuat kondisi tubuh berkurang vitalitasnya. Menua merupakan suatu proses menghilangnya secara perlahan-lahan kemampuan jaringan untuk memperbaiki, mengganti diri, dan mempertahankan struktur dan fungsi normalnya. Dengan demikian menua ditandai dengan kehilangan secara progresif jaringan aktif tubuh yang sudah dimulai sejak usia 40 tahun disertai dengan menurunnya metabolisme basal sebesar $2 \%$ setiap tahunnya yang disertai dengan perubahan di semua sistem di dalam tubuh manusia.

Penelitian yang dilakukan Sunjaya (2009), juga menemukan bahwa kelompok umur yang paling banyak menderita Diabetes mellitus adalah kelompok umur 45-52 tahun. Peningkatan risiko diabetes seiring dengan umur, khususnya pada usia lebih dari 40 tahun, disebabkan karena pada usia tersebut mulai terjadi peningkatan intoleransi glukosa. Adanya proses penuaan menyebabkan berkurangnya kemampuan sel $\beta$ pankreas dalam memproduksi insulin. Selain itu juga, individu yang berusia lebih tua terdapat penurunan aktivitas mitokondria di sel-sel otot sebesar 35\%. Hal ini berhubungan dengan peningkatan kadar lemak di otot sebesar 30\% dan memicu terjadinya resistensi insulin.

Berdasarkan dari data umur responden dan umur awal responden terkena DM, dapat diketahui bahwa paling lama responden menderita DM yaitu selama 18 tahun dan paling rendah adalah selama $<1$ tahun (5 bulan). Semakin lama responden menderita Diabetes mellitus maka responden akan mempunyai pengetahuan dan pengalaman yang paling baik dalam hal diet sehingga akan patuh terhadap diet yang dianjurkan. Menurut Widyaningsih (2013) seseorang yang lama menderita penyakit akan mampu merespon penyakit tersebut dengan rajin mengikuti pengobatan.

\section{Pendidikan}

Tingkat pendidikan merupakan jenjang pendidikan formal yang berhasil ditamatkan oleh responden yang didapatkan dari wawancara menggunakan alat ukur kuesioner. Kategori tingkat pendidikan yaitu tidak sekolah, SD, SMP, SMA dan Perguruan Tinggi. Berdasarkan hasil penelitian didapatkan bahwa sebagian besar pendidikan terakhir pasien Diabetes mellitus yang digunakan sebagai sampel adalah SMA dengan persentase $36,7 \%$ serta paling sedikit yaitu tamatan SD dengan persentase $16,7 \%$.

Pendidikan merupakan hal yang sangat penting, karena pendidikan mempengaruhi pola pikir seseorang tentang sesuatu hal yang nantinya akan berpengaruh dalam pengambilan suatu keputusan tertentu. Menurut Notoatmodjo (2010) semakin tinggi tingkat pendidikan, semakin besar pengetahuan dan semakin mudah mengembangkan pengetahuan dan teknologi yang berdampak pada peningkatan kesejahteraan seseorang.

Tingkat pendidikan memiliki pengaruh terhadap kejadian penyakit Diabetes Mellitus Tipe 2. Orang yang tingkat pendidikannya tinggi biasanya akan memiliki banyak pengetahuan tentang kesehatan. Dengan adanya pengetahuan tersebut orang akan memiliki kesadaran dalam menjaga kesehatannya (Irawan, 2010). Semakin tingginya tingkat pendidikan maka diharapkan akan semakin luas pula pengetahuan responden serta semakin mudah dan cepat pula untuk menerima berbagai informasi dari berbagai media khususnya tentang gizi dan kaitannya dengan kesehatan. Hal ini didukung oleh teori Santoso (2004) dalam Widyaningsih (2013), tingkat pendidikan berpengaruh pada pengetahuan yang dimiliki seseorang. Semakin tinggi tingkat pendidikan yang pernah ditempuh maka semakin mudah dalam menyerap informasi baru. Pendidikan dapat ditempuh melalui jalur formal maupun non formal.

Teori yang dikemukan tersebut sesuai dengan hasil penelitian, dimana dari 21 responden yang memiliki pendidikan yang tinggi (tamatan SMA dan PT) memiliki pengetahuan yang baik yang ditandai dengan responden dapat menjawab pertanyaan tentang terapi diet pada kuesioner yang diberikan. Begitupun sebaiknya responden yang memiliki pendidikan rendah sebagian besar tidak memiliki pengetahuan yang baik tentang kesehatan. Selain itu, responden yang memiliki pendidikan rendah (SD dan SMP) sulit menerima informasi/pengetahuan kesehatan yang diberikan saat dilakukan konsultasi gizi.

\section{Pekerjaan}

Tingkat pekerjaan merupakan aktivitas tetap yang dilakukan responden baik di dalam maupun di luar rumah untuk memperoleh penghasilan. Data tingkat pekerjaan responden didapat menggunakan alat ukur berupa kuesioner dengan cara wawancara. Kategori pekerjaan terdiri dari ibu rumah tangga, PNS, pegawai swasta, wiraswasta, buruh dan pensiunan. Berdasarkan dari hasil penelitian, didapatkan bahwa sebagian besar pekerjaan responden adalah ibu rumah tangga yaitu 14 orang dengan persentase $46,7 \%$. Sedangkan pekerjaan responden yang paling sedikit adalah pegawai swasta yaitu 1 orang dengan persentase $3,3 \%$. 
Dari hasil penelitian yang dilakukan, didapat bahwa sebagian besar pekerjaan responden adalah ibu rumah tangga usia $>45$ tahun dan kebanyakan ibu rumah tangga tinggal bersama anaknya serta tidak mengerjakan pekerjaan rumah tangga sehingga rata-rata memiliki aktivitas sehari-hari yang tergolong ringan.

Menurut Grant et al., (2009) dalam Mongisidi (2014), jenis pekerjaan erat kaitannya dengan kejadian DM. Pekerjaan seseorang mempengaruhi tingkat aktivitas fisiknya. Penelitian menunujukkan bahwa orang yang tidak memiliki perkerjaan berisiko 1,5 kali lebih besar terkena DM Tipe 2 dibandingkan mereka yang memiliki pekerjaan. Penelitian dari Grant yang berjudul Gender-Specific Epidemiology of Diabetes di Adelaide, Australia mendapatkan hasil bahwa mereka yang memiliki status pekerjaan tidak bekerja beresiko terkena Diabetes Mellitus. Pada kelompok kategori tidak bekerja cenderung kurang melakukan aktivitas fisik sehingga proses metabolisme atau pembakaran kalori tidak berjalan dengan baik. Aktivitas fisik memegang peranan penting dalam upaya pencegahan diabetes mellitus.

Penelitian ini sejalan dengan penelitian Fikasari (2012), bahwa seseorang yang teratur melakukan aktivitas fisik dapat menurunkan risiko terjadinya penyakit Diabetes mellitus tipe 2 sebesar 0,442 kali dibandingkan yang tidak teratur/tidak pernah melakukan aktivitas fisik. Faktor risiko terjadinya Diabetes mellitus tipe 2, karena aktivitas fisik dapat menurunkan berat badan dan memperbaiki sensitifitas terhadap insulin, sehingga dapat memperbaiki kendali glukosa dalam darah (Misnadiarly, 2006).

\section{Konsultasi Gizi}

Konsultasi gizi merupakan suatu proses dalam membantu seseorang mengerti tentang keadaan dirinya, lingkungannya dan hubungan dengan keluarganya dalam membangun kebiasaan yang baik termasuk makan sehingga menjadi sehat,aktif dan produktif. Berdasarkan dari hasil penelitian, didapatkan bahwa sebagian besar responden pernah melalukan konsultasi gizi dengan persentase sebesar $63,3 \%$ atau sebanyak 19 orang, sedangkan sisanya sebanyak 11 orang belum pernah melakukan konsultasi gizi. Dari hasil wawancara, diketahui bahwa responden yang belum pernah melakukan konsultasi dikarenakan beberapa alasan, diantaranya sudah terlalu lama menunggu hasil laboratorium (satu jam) sehingga responden jenuh dan akhirnya langsung pulang walaupun telah dirujuk oleh dokter di poli penyakit dalam ke poli gizi. Selain itu, alasan responden belum pernah melakukan konsultasi gizi karena responden yang datang merupakan pasien BPJS, sehingga responden malas mengurus keperluan surat pengantar rujukan dari dokter di poli penyakit dalam ke poli gizi dan memilih untuk langsung pulang.

Konseling gizi berkaitan dengan pemahaman atau edukasi pasien tentang penyakit Diabetes mellitus. Pada dasarnya edukasi pada Diabetes mellitus adalah perawatan mandiri sehingga seakan-akan pasien menjadi dokternya sendiri dan juga mengetahui kapan pasien harus pergi ke dokter atau ahli gizi untuk mendapatkan pengarahan lebih lanjut. Edukasi yang cukup akan menghasilkan kontrol Diabetes yang baik dan mencegah perawatan di rumah sakit (VitaHeath 2006 dalam Hardiana 2015).

Menurut penelitian yang dilakukan oleh Hardiana (2015), terdapat hubungan antara konseling gizi terhadap keberhasilan diet pada penderita Diabetes Mellitus. Penderita Diabetes mellitus yang memanfaatkan konseling gizi dengan baik akan mempunyai peluang 3,92 kali untuk berhasil diet dibandingkan penderita yang kurang memanfatkan konseling gizi. Hal ini dikarenakan konseling bertujuan untuk mendidik pasien sehinggga pengetahuan pasien terhadap keberhasilan akan meningkat dan hal ini akan mendorong pada perubahan perilaku.

\section{Gambaran Pengetahuan Pasien tentang Terapi Diet}

Tingkat pengetahuan tentang terapi diet merupakan kemampuan responden menjawab pertanyaan tentang pengaturan makan mengenai terapi diet untuk penderita DM tipe 2. Berdasarkan dari hasil penelitian, dapat diketahui bahwa responden yang memiliki tingkat pengetahuan yang baik yaitu sebanyak 21 orang atau $70 \%$. Sedangkan responden yang memiliki tingkat pengetahuan kurang baik hanya 9 orang atau sebesar $30 \%$. Hal ini menunjukan bahwa sebagian besar responden memiliki pengetahuan yang baik tentang terapi diet Diabetes mellitus walaupun responden rata-rata berpendidikan terakhir SMA. Hal ini disebabkan karena sebagian besar responden pernah melakukan konsultasi gizi dengan tenaga kesehatan/ ahli gizi. Sehingga pengetahuan yang didapat secara informal bukan secara formal. Pengetahuan responden yang baik tentang terapi diet DM di tandai dengan pada saat dilakukan wawancara banyak responden yang telah mengerti tentang prinsip dan bagaimana penatalaksanaan diet untuk pasien DM, seperti mengenai jumlah makanan, jenis makanan dan jadwal makan yang dianjurkan terutama mengenai bahan-bahan 
makanan apa saja yang dapat menaikkan kadar gula dengan cepat dan sebaliknya.

Menurut Notoatmodjo (2010), menyatakan bahwa salah satu faktor yang menentukan perilaku kesehatan seseorang adalah tingkat pengetahuan. Pasien diabetes relatif dapat hidup normal bila mengetahui dengan baik keadaan dan cara penatalaksanaan penyakit tersebut. Perubahan pola penyakit dari akut ke kronis atau seseorang yang memiliki penyakit kronis, cenderung akan memiliki pengetahuan meningkat. Pasien berusaha untuk mencari informasi sejelas-jelasnya mengenai penyakitnya, baik dari petugas kesehatan maupun dari media informasi lainnya. Sebagian besar peningkatan jumlah penderita DM tipe 2 karena kurangnya pengetahuan tentang pengelolaan DM. Pengetahuan pasien tentang pengelolaan DM sangat penting untuk mengontrol kadar glukosa darah. Penderita DM yang mempunyai pengetahuan yang cukup tentang diabetes, kemudian selanjutnya mengubah perilakunya, akan dapat mengendalikan kondisi penyakitnya sehingga dapat hidup lebih lama.

\section{Gambaran Indeks Glikemik Bahan Makanan yang Dikonsumsi}

Indeks Glikemik bahan makanan yang dikonsumsi pasien merupakan bahan makanan yang dikonsumsi responden dalam sehari yang mengandung indeks glikemik yang diperoleh berdasarkan perhitungan IG menyeluruh. Berdasarkan dari hasil penelitian, dapat diketahui bahwa responden Diabetes mellitus tipe 2 paling banyak mengonsumsi bahan makanan yang mengandung indeks glikemik rendah yaitu 14 orang dengan persentase sebesar 46,7\%, sedangkan sisanya responden mengonsumsi bahan makanan dengan indeks glikemik tinggi yaitu 16 orang dengan persentase 53,3\%.

Informasi IG pangan dapat membantu penderita DM dalam memilih makanan yang tidak menaikkan kadar gula darah secara drastis, sehingga kadar gula darah dapat dikontrol pada tingkat yang aman. Pangan IG rendah membantu orang untuk mengendalikan rasa lapar, selera makan, dan kadar gula darah. Jadi, pangan dengan IG rendah dapat membantu mengurangi kelebihan berat badan (Widowati, 2007). Indeks glikemik membantu penderita diabetes dalam menentukan jenis pangan karbohidrat yang dapat mengendalikan kadar glukosa darah. Dengan mengetahui IG pangan, penderita diabetes dapat memilih makanan yang tidak menaikkan kadar glukosa darah secara drastis sehingga kadar glukosa darah dapat dikontrol pada tingkat yang aman (Rimbawan, 2004).
Hal ini sejalan dengan penelitian yang dilakukan oleh Annisa (2015) mengenai hubungan konsumsi bahan makanan yang mengandung indeks glikemik dengan kadar gula darah pada pasien DM-tipe 2 di RSUD Abdul Moeloek, dimana diketahui bahwa adanya hubungan yang bermakna antara indeks glikemik bahan makanan yang dikonsumsi dengan kadar gula darah pasien Diabetes mellitus tipe 2. Pangan yang mempunyai indeks glikemik tinggi bila dikonsumsi akan meningkatkan kadar gula dalam darah dengan cepat dan tinggi. Sebaliknya, seseorang yang mengonsumsi pangan berindeks glikemik rendah maka peningkatan kadar gula dalam darah berlangsung lambat dan puncak kadar gula darahnya rendah.

Berdasarkan hasil wawancara, responden kebanyakan berpuasa sehingga pola makannya hanya 2 kali, yaitu saat sahur dan buka puasa. Dari jenis makanan yang dikonsumsi, responden paling banyak mengonsumsi bahan makanan yang mengandung indeks glikemik tinggi seperti nasi putih $(\mathrm{IG}=84)$, kentang rebus $(\mathrm{IG}=76)$, roti tawar ( $\mathrm{IG}=70)$, kurma kering ( $\mathrm{IG}=124)$, dan labu siam $(\mathrm{IG}=75)$. Selain itu, responden mengonsumsi dalam jumlah yang banyak, seperti nasi putih 200 gram, kentang rebus 50 gram, kurma kering 25 gram (5 buah kurma). Dari wawancara yang dilakukan diketahui pula masih terdapat responden yang tidak mengganti gula pasir dengan gula buatan, tetapi justru menggantinya dengan gula kelapa dan gula aren dengan anggapan bahwa gula kelapa dan gula aren lebih baik dari gula pasir. Hal ini tidak sesuai dengan anjuran makan untuk penderita diabetes, karena dapat meningkatkan kadar gula darah dengan cepat.

\section{Hubungan Pengetahuan tentang Terapi Diet dengan Indeks Glikemik Bahan Makanan yang Dikonsumsi Pasien Diabetes Mellitus Tipe II}

Berdasarkan hasil penelitian menunjukkan bahwa responden yang mengonsumsi bahan makanan dengan indeks glikemik rendah sebanyak 14 responden, terdapat 14 responden $(66,7 \%)$ memiliki pengetahuan yang baik dan sebanyak 0 responden $(0 \%)$ memiliki pengetahuan yang tidak baik tentang terapi diet. Sedangkan responden yang mengonsumsi bahan makanan dengan indeks glikemik tinggi sebanyak 16 responden, terdapat 7 responden $(33,3 \%)$ memiliki pengetahuan yang baik dan sebanyak 9 responden $(100 \%)$ memiliki pengetahuan yang tidak baik tentang terapi diet.

Hasil uji statistik didapatkan $p$-value 0,001 $(p<0,05)$. Hal ini menunjukkan bahwa terdapat 
hubungan yang bermakna antara pengetahuan tentang terapi diet dengan indeks glikemik yang dikonsumsi pasien Diabetes mellitus tipe II.

Dari hasil penelitian yang dilakukan oleh Widyaningsih (2013), terdapat hubungan yang bermakna antara pengetahuan dengan kepatuhan diet Diabetes mellitus dalam mengatur jenis bahan makanan yang akan dikonsumsi. Dalam hasil penelitian tersebut dijelaskan bahwa responden yang memiliki pengetahuan baik memiliki kepatuhan diet yang baik pula yang ditandai dengan mengonsumsi bahan-bahan makanan yang tidak menaikkan kadar gula darah dengan cepat begitupun sebaliknya. Hasil penelitian ini sejalan dengan penelitian Maemunah (2010) yang menyimpulkan ada hubungan yang bermakna antara tingkat pengetahuan dengan kepatuhan menjalankan terapi diet Diabetes mellitus di Puskesmas Mranggen I Kabupaten Demak.

Penelitian ini sejalan dengan penelitian yang dilakukan oleh Tandayu (2014), dimana diketahui terdapat hubungan yang bermakna antara pengetahuan gizi dengan perilaku konsumsi makanan. Dalam penelitian tersebut dijelaskan bahwa responden yang memiliki pengetahuan gizi yang baik cenderung mengonsumsi bahan makanan yang mengandung indeks glikemik yang rendah seperti bihun, beras merah dan ubi. Begitupun sebaliknya, responden yang memiliki pengetahuan yang kurang baik tentang gizi cenderung mengonsumsi bahan makanan yang mengandung indeks glikemik tinggi, seperti nasi putih, mie, roti putih, dan macaroni.

Menurut Notoatmodjo (2010) pengetahuan atau kognitif merupakan domain yang sangat penting untuk terbentuknya suatu tindakan, perilaku yang didasari pengetahuan akan lebih langgeng dari pada yang tidak didasari pengetahuan. Pengetahuan tentang kesehatan dapat membantu individu-individu tersebut untuk beradaptasi dengan penyakitnya, mencegah komplikasi dan mematuhi program terapi dan belajar untuk memecahkan masalah ketika menghadapi situasi baru. Menurut Hendro (2010) menyatakan pengetahuan diet terhadap kepatuhan diet bisa saja dipengaruhi oleh seberapa sering melakukan konsultasi dengan tenaga kesehatan, dan penderita lainnya sehingga informasi yang didapatkan juga sudah banyak dari berbagai media maupun penyuluhan kesehatan. Seseorang yang memiliki pendidikan rendah tetapi mendapatkan informasi yang baik dari berbagai media akan meningkatkan pengetahuannya. Kemudahan untuk memperoleh suatu informasi dapat membantu mempercepat seseorang memperoleh pengetahuan yang baru.

Pengetahuan tentang indeks glikemik bahan makanan dapat membantu penderita DM dalam memilih makanan yang tidak menaikkan kadar gula darah secara drastis, sehingga kadar gula darah dapat dikontrol pada tingkat yang aman. Pangan IG rendah membantu orang untuk mengendalikan rasa lapar, selera makan, dan kadar gula darah. Jadi, pangan dengan IG rendah dapat membantu mengurangi kelebihan berat badan (Widowati, 2007). Indeks glikemik membantu penderita diabetes dalam menentukan jenis pangan karbohidrat yang dapat mengendalikan kadar glukosa darah. Dengan mengetahui IG pangan, penderita diabetes dapat memilih makanan yang tidak menaikkan kadar glukosa darah secara drastis sehingga kadar glukosa darah dapat dikontrol pada tingkat yang aman (Rimbawan, 2004).

Untuk itu responden sebaiknya mencari informasi tentang diet DM baik dari media massa, internet, atau mengikuti konseling gizi dan penyuluhan untuk meningkatkan pengetahuan dan kesadaran dalam mematuhi anjuran diet yang diberikan untuk penderita DM terutama dalam pemilihan bahan makanan terutama yang bernilai indeks glikemik rendah sehingga kadar gula darah dapat selalu terkontrol. Selain itu, untuk rumah sakit sebaiknya lebih proaktif memberikan konsultasi gizi dan penyuluhan gizi serta lebih meningkatkan pelayanan gizi untuk meningkatkan pengetahuan dan kesadaran pasien Diabetes mellitus Tipe 2 terutama pengetahuan mengenai indeks glikemik bahan makanan. Selain itu, dapat menyediakan media pendidikan kesehatan bagi penderita DM seperti leaflet, lembar balik, yang dapat dimanfaatkan untuk penyuluhan dan konseling gizi.

\section{SIMPULAN}

Berdasarkan hasil penelitian dari penelitian yang dilakukan, dapat disimpulkan sebagai berikut: karakteristik jenis kelamin responden yang paling banyak adalah perempuan $(56,7 \%)$, distribusi karakteristik umur sebagian besar responden berkisar 51-60 tahun $(43,3 \%)$ dan umur awal responden terkena Diabetes mellitus tipe 2 paling banyak berkisar antara 41-50 tahun (40\%). Sedangkan paling lama responden menderita sakit DM yaitu 18 tahun. Distribusi karakteristik pendidikan terakhir responden ratarata adalah SMA (36,7\%). Karakteristik pekerjaan responden sebagian besar adalah ibu 
rumah tangga $(46,7 \%)$, sebagian besar pernah melakukan konsultasi gizi oleh ahli gizi $(63,3 \%)$, sebagian besar responden memiliki tingkat pengetahuan yang baik tentang terapi diet (70\%), indeks glikemik bahan makanan yang dikonsumsi responden sebagian besar tinggi $(53,3 \%)$.

Ada hubungan yang bermakna antara pengetahuan tentang terapi diet dengan indeks glikemik bahan makanan yang dikonsumsi pasien Diabetes mellitus tipe II di Poli Penyakit Dalam RSUD Dr. H. Abdul Moeloek Provinsi Lampung tahun $2016(p=0,001)$.

\section{SARAN}

Sebaiknya ahli gizi rumah sakit lebih proaktif memberikan konsultasi gizi dan

\section{DAFTAR PUSTAKA}

Annisa, Dias Rindi. 2015. Hubungan Konsumsi Bahan Makanan yang Mengandung Indeks Glikemik dengan Kadar Gula Darah Sewaktu pada Pasien Diabetes mellitus tipe 2 di Ruang Rawat Jalan Puskesmas Kemiling Tahun 2015. Karya Tulis Ilmiah, Jurusan Gizi Poltekkes Kemenkes Tanjung Karang, Lampung.

Badan Pengembangan dan Penelitian Kemenkes RI. 2013. Laporan Riset Kesehatan Dasar 2013. Kemenkes RI: Jakarta.

Badan Pengembangan dan Penelitian Kemenkes RI. 2007. Laporan Riset Kesehatan Dasar 2007. Kemenkes RI: Jakarta.

Bilous, Rudy dan Donelly, Richard. 2014. Buku Pegangan Diabetes. Jakarta: Bumi Merdeka.

Ernawati. 2013. Penatalaksanaan Keperawatan Diabetes Mellitus. Jakarta: Mitra Wacana Media.

Gabby Mongisidi. 2014. Hubungan Antara Status Sosio-Ekonomi dengan Kejadian Diabetes Melitus Tipe 2 Di Poliklinik Interna Blu Rsup Prof. Dr. R. D. Kandou Manado. Skripsi, Fakultas Kesehatan Masyarakat Universitas Sam Ratulangi.

Hardiana, Hedy. 2015. Hubungan Konseling Gizi Terhadap Keberhasilan Diet Pada Penderita Diabetes Melitus di RS Prikasih. Jurnal Ilmu Keperawatan Indonesia. Vol. 5, No. 4, Desember 2015.

Helmawati, Triana. 2014. Hidup Sehat Tanpa Diabetes. Yogyakarta: Notebook.

Hendro. 2010. Pengaruh Psikososial terhadap Pola Makan Penderita Diabetes Mellitus penyuluhan gizi serta lebih meningkatkan pelayanan gizi untuk meningkatkan pengetahuan dan kesadaran pasien Diabetes mellitus Tipe 2 terutama pengetahuan mengenai indeks glikemik bahan makanan. Selain itu, dapat menyediakan media pendidikan kesehatan bagi penderita DM seperti leaflet, lembar balik, yang dapat dimanfaatkan untuk penyuluhan dan konseling gizi.

Bagi peneliti selanjutnya diharapkan dapat dilakukan penelitian lebih lanjut pada pasien Diabetes mellitus tipe II dengan desain penelitian case control tentang pengetahuan yang dimiliki responden dan indeks glikemik bahan makanan yang dikonsumsi yang dibandingkan dengan yang pernah melakukan konsultasi gizi dan yang tidak pernah melakukan konsultasi gizi.

di Rumah Sakit Umum Daerah Kabupaten Deli Serdang Tahun 2009. Tesis FKM Universitas Sumatra Utara. Medan.

Irawan, Dedi. 2010. Prevalensi dan Faktor Risiko Kejadian Diabetes Melitus Tipe 2 di Daerah Urban Indonesia (Analisa Data Sekunder Riskesdas 2007). Thesis Universitas Indonesia.

Jelantik dan Haryati. 2014. Hubungan Faktor Risiko Umur, Jenis Kelamin, Kegemukan dan Hipertensi dengan Kejadian Diabetes mellitus Tipe II di Wilayah Kerja Puskesmas Mataram. Media Bina Ilmiah, Volume 8, No. 1, 2014.

Laili, dkk. 2012. Edukasi dengan Pendekatan Prinsip Diabetes Melitus Self Management Education (DSME) Meningkatkan Perilaku Kepatuhan Diet pada Penderita Diabetes Melitus Tipe 2. Tersedia http://www.journal.unair.ac.id (Diakses pada 28 Desember 2015).

Maemunah. 2010. Hubungan yang Bermakna Antara Tingkat Pengetahuan dengan Kepatuhan Menjalankan Terapi Diet Diabetes mellitus di Puskesmas Mranggen I Kabupaten Demak. Skripsi. Fakultas Kesehatan Masyarakat. Universitas Indonesia.

Maulana. 2008. Mengenal Diabetes Melitus. Jakarta: Ar-Russ Media Group.

Misnadiarly. 2006. Diabetes Mellitus: Ulcer, Infeksi, Gangren. Jakarta: Penerbit Popular Obor.

Notoatmodjo, S. 2010. Ilmu Perilaku Kesehatan. Jakarta: Rineka Cipta. 
PERKENI. 2011. Konsensus Pengelolaan dan Pencegahan Diabetes Melitus Tipe 2 di Indonesia. PERKENI: Jakarta.

Pramudiarja, Uyung. 2011. Ukuran Tubuh Manusia 100 Tahun Mendatang Bakal Menyusut.

http://www.detikhealth.com/read/2011/06/ 16/092859/1661459/763/ukuran-tubuhmanusia-100-tahun-mendatang-bakalmenyusut?ld991103763 (Diakses pada 11 Juli 2016).

Prihaningtyas, Rendi Aji. 2013. Hidup Manis Dengan Diabetes. Yogyakarta: Media Pressindo.

Pusat Data dan Informasi Kemenkes RI. 2012. Gambaran Penyakit Tidak Menular di Rumah Sakit di Indonesia Tahun 2009 dan 2010. Buletin Jendela Data dan Informasi Kesehatan, Volume 2, Semeseter 2, Jakarta.

Rimbawan, AS. 2004. Indeks Glikemik Pangan. Jakarta: Penebar Swadaya Jakarta

Rusimah. 2010. Hubungan Tingkat Pendidikan Dan Pengetahuan Gizi Dengan Kepatuhan Diet Pada Penderita Diabetes mellitus (Diabetisi) di Ruang Rawat Inap Rsud Dr.H.Moch Ansari Saleh Banjarmasin Tahun 2010. Skripsi Sarjana, Program Studi Gizi Sekolah Tinggi Ilmu Kesehatan Husada Borneo, Banjarbaru.
Smeltzer, S.C. dan Brenda G. Bare. 2002. Buku Ajar: Keperawatan Medik Bedah. Edisi 8. Jakarta: Penerbit buku kedokteran EGC.

Sunjaya, I Nyoman. 2009. Pola Konsumsi Makanan Tradisional Bali sebagai Faktor Risiko Diabetes Melitus Tipe 2 di Tabanan. Jurnal Skala Husada. Vol. 6 No.1 hal: 75-81.

Tandayu, Fernando. 2014. Pengaruh Motivasi, Pengetahuan serta Tindakan Olahraga terhadap Tindakan Konsumsi Pangan Pelaku Fitness Usia Dewasa. Skripsi Sarjana, Fakultas Ekologi Manusia Institut Pertanian Bogor, Bogor.

Trisnawati, SK. 2013. Faktor Risiko Kejadian Diabetes Melitus Tipe II Di Puskesmas Kecamatan Cengkareng Jakarta Barat Tahun 2012. Jurnal Ilmiah Kesehatan. Volume 5, No. 1, 2013.

Widyaningsih. 2013. Hubungan Antara Pengetahuan Dan Sikap Penderita Diabetes mellitus Dengan Kepatuhan Diet Diabetes mellitus Di RSUD Am. Parikesit Kalimantan Timur. Jurnal Keperawatan Medikal Bedah. Volume 1, No. 1, Mei 2013; 58-74.

Widowati. 2007. Peran Pangan Indeks Glikemik Rendah.

http://pascapanen.litbang.pertanian.go.id/in dex.php/id/berita/109 (Diakses pada 1 Januari 2016). 